\title{
The Influence of Blended Learning to Understanding Concept
}

\author{
WalibAbdullah $^{\mathrm{a}}$, InyomanSudanaDegeng ${ }^{\mathrm{b}}, \mathrm{Henry}$ Praherdhiono $^{\mathrm{c}}$, Sulthoni $^{\mathrm{d}}$ \\ alecturer at Institut Agama Islam Al-Khairat, Doctoral Student at UniversitasNegeri Malang, Malang, Indonesia \\ b,c,d UniversitasNegeri Malang, Malang, Indonesia \\ awalib.abdullah.1701219@students.um.ac.id
}

Article History: Received: 10 November 2020; Revised 12 January 2021 Accepted: 27 January 2021; Published online: 5 April 2021

\begin{abstract}
This study aims to explain blended learning and learning styles towards students' conceptual understanding. This study was designed as a quasi-experiment involving 84 students of the IslamicsEducation Department, Faculty of Education of Islamics Institute of Al-KhairatPamekasan, Indonesia. The research data were collected using a test. Before the study, tests were carried out for the experimental and control groups. Data were analyzed using descriptive statistics and ANOVA test with pre-test scores as covariates. The level of significance was determined at $\alpha=0.05$. The results showed that (1) there were differences in learning outcomes between those taught with the blended learning model and those taught with the conventional learning model. (2) The difference in learning outcomes between groups of students who had to learn styles and groups of students with low learning discipline. Student learning discipline had an essential role in the learning process. These findings indicated that blended learning could dominate the learning outcomes of students' conceptual mastery. Future research might be able to discuss the results of tests conducted to determine the effectiveness of mastery of learning concepts with other learning models.
\end{abstract}

Keywords: blended learning, understanding the concept of online and offline, face to face

\section{Introduction}

The existence of the Coronavirus Disease 2019 (COVID-19) Pandemic has dramatically changed the higher education system with a striking change that initially implemented face-to-face learning switching to online learning. Many universities implemented online learning at the beginning of the outbreak of the 2019 Coronavirus Disease Pandemic (COVID-19), but after there was a policy from the government, namely, a new routine, did much face-to-face and online learning or what is called Blended learning (Sukendro et al., 2020). The use of mobile technology has many innovations in the learning approach with various models developed by educational experts or practitioners. According to Bonk \& Graham, Mac Donald \& McAteer, learning combines online learning with face-to-face learning or what is known as blended learning (Miyazoe \& Anderson, 2010).

The use of technology in learning has been developed in education to make it easier for students to interact with teachers. Many internet features are used as instructional media to provide material for assignments provided in these features as other web features. The learning system is combined with conventional learning in face-toface learning and minimizes face-to-face activities (Krasnova \& Demeshko, 2015).

Blended learning is a learning system that is renewed by the use of online-based digital technology. Blended learning also changes the learning system, which is a Lecturer has mastered the learning or is centered on Lecturer, so in this blended learning, learning innovation provides opportunities for students to be more active in the learning process. Blended learning is learning that is more effective, structured, and more flexible in its use. The use of blended learning can effectively make students think critically and creatively(Atia \& Elsaid, 2000).

According to Osguthorpe and Graham, they explained that considering implementing blended learning to compensate for the weaknesses of both face-to-face learning or E-learning so that there can be mutual communication/interaction between lecturers and students and online learning is not found in face-to-face learning. It is also known that face-to-face learning still requires online learning with various applications developed by reference education (Cohen, 1998).

In this study, blended learning was tested using the LMS (Learning Management System) design. The Lecturer designed learning effortlessly with the classroom's help - all materials are placed in the same application and a video explaining the application's material. The final assignments and exams are carried out online. In this learning, 50\% face-to-face learning and 50\% online learning with different learning strengths are applied. It is hoped that learning will be more exciting and more effective during the Covid-19 period. 


\section{Theoretical Review}

\section{Blended learning models}

Various definitions of blended learning have developed along with the development of information and communication technology. The definition of blended learning refers to how teachers maximize the use of face-toface learning and online learning. Blended learning in research is a fun learning design and makes students active in learning both in the class and outside the class; it is necessary to design a learning model that combines online, offline, and face-to-face(Schober et al., 2012). Obukhov said that blended learning combines various elements of face-to-face teaching, including personalized learning, social interaction and direct interaction, and the use of elearning to make learning more flexible than conventional learning. The application of blended learning in class is online and integrates content into learning (Buran \& Evseeva, 2015).

Blended Learning has the potential to create an independent, interactive, meaningful learning atmosphere and can be used as a medium for discussion, asking questions, providing feedback, sharing information, and evaluating. Blended Learning provides flexible free time for students to make it easier to understand learning material. The Blended Learning application can be used as a medium for discussion, sharing information, evaluating online. Torrisi-Steele's (2011) opinion regarding blended learning is learning enriched with studentcentered learning experiences made possible by harmonious integration, which combines face-to-face learning with technology-assisted online learning (Prasad et al., 2018).

Blended learning is a learning approach with various techniques and technologies in learning that aims to provide a more effective and efficient learning experience. Blended learning usually contains two or more learning techniques with different approaches. However, currently, most designs are online learning. This blended learning design allows teachers to combine face-to-face learning with online learning to interact directly with the teacher or learners with unlimited space and time (Köse, 2010). has described three features of blended learning which include: Face-to-face learning: In a face-to-face educational environment, teachers and students are in the same condition and at the same time (Sriarunrasmee et al., 2015).

Blended learning enables students who are involved in lesson planning to develop creative and critical thinking successfully. Besides, blended learning allows students to be independent while studying outside the classroom to learn the material. Self-learning provides constant feedback without teacher assistance. Students can easily find their results and see their progress. So the teaching role changes from being a facilitator who helps monitor and assesses learners' progress, allowing them to learn independently (Berga et al., 2021). Blended learning is a pedagogical approach that combines the effectiveness and opportunities of classroom socialization with active learning that is technologically enhanced by the online environment's potential; it does not always correspond to the ratio of the delivery modality.

\section{Research Method}

The research design was designed using a quasi-pretest post-test equivalent control group design experiment with a 2X2 factorial version. This study's design considers the focus of attention on the independent variable (independent), namely blended learning and conventional learning, while the dependent variable understands the concept. The conceptual understanding variable as the dependent variable (Y), the learning model variable as an independent variable which consists of two categories, namely blended learning (X1) and conventional learning variables (X2), as the moderator variable consists of two categories, namely active learning styles (B1) and reflective learning styles (B2).

Based on the three variables studied, a $2 \times 2$ factorial design was prepared. The relationship between variables in the study refers to the opinion of Miles and Huberman's [22], which is shown in Figure 1 below 


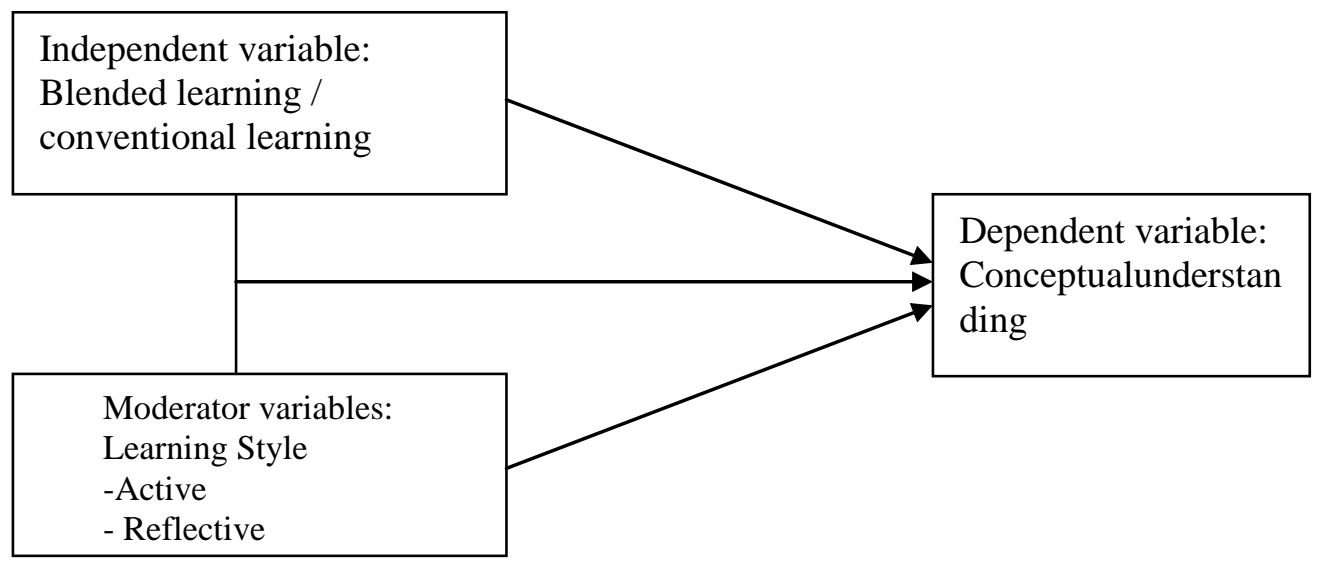

Testing the requirements of this analysis will be used. The requirements analysis test is carried out to detect whether the data obtained meets the analysis techniques' requirements using analysis techniques planned following the research objectives. The basic assumptions that must be met before the data are analyzed using ANOVA analysis techniques are; 1) normal data distribution and 2) homogeneous data. The Kolmogorov Smimov normality test's basic concept is to compare the distribution of data (to which normality will be approved) with the standard normal distribution. The distribution of standard norms is data that has been converted into Z-scores and is considered normal. The Kolmogorov Smimov test application happens if the significance is 0.05 , which means that the data to be tested has a significant difference with standard average data, meaning that the data is not normal. The homogeneity assumption test is a test of the difference between the two groups, with the difference is not the mean value but the group variance.

\section{Research Result}

The prerequisite test is used to detect whether the data obtained meets the analysis techniques' requirements using analysis techniques that are planned following the research objectives. The basic assumptions that must be met before the data are analyzed using the ANOVA analysis technique are as follows

\section{Normality test}

\begin{tabular}{|c|c|c|c|c|c|c|c|}
\hline \multicolumn{7}{|l|}{ Normality Test } & Shapiro-Wilk \\
\hline & Class & Statistic & df & Sig. & Statistic & Df & Sig. \\
\hline & Pre-test Experiment & ,142 & 22 &, $200^{*}$ & ,935 & 22 & ,159 \\
\hline Understanding & post-test Control &, 112 & 22 &, $200^{*}$ & ,953 & 22 & ,361 \\
\hline Concept & $\begin{array}{l}\text { Pre-test control } \\
\text { post-test control }\end{array}$ & $\begin{array}{l}, 111 \\
, 174\end{array}$ & $\begin{array}{l}22 \\
22\end{array}$ & $\begin{array}{l}, 200^{*} \\
, 080\end{array}$ & $\begin{array}{l}, 954 \\
, 956\end{array}$ & $\begin{array}{l}22 \\
22\end{array}$ & $\begin{array}{l}, 373 \\
, 419\end{array}$ \\
\hline $\begin{array}{l}* \text { This is a lowe } \\
\text { a. Lilliefors Sign }\end{array}$ & $\begin{array}{l}\text { bound of true signif } \\
\text { ficance Correction }\end{array}$ & ance. & & & & & \\
\hline
\end{tabular}

After having the normality test on the results of this research, it shows the output results with a significance value (sig) for all data, either Kolmograv-Smirnov or Shapiro-Wilk>0.05, with the data can be interpreted that the research data is normally distributed. We can use parametric statistics (paired-sample t test and independent sample T test) to conduct research data because the data is normally distributed. Simultaneously, the results of the paired sample t-test can be seen in the following table.

\section{Paired sample t-test}

Paired Samples Test

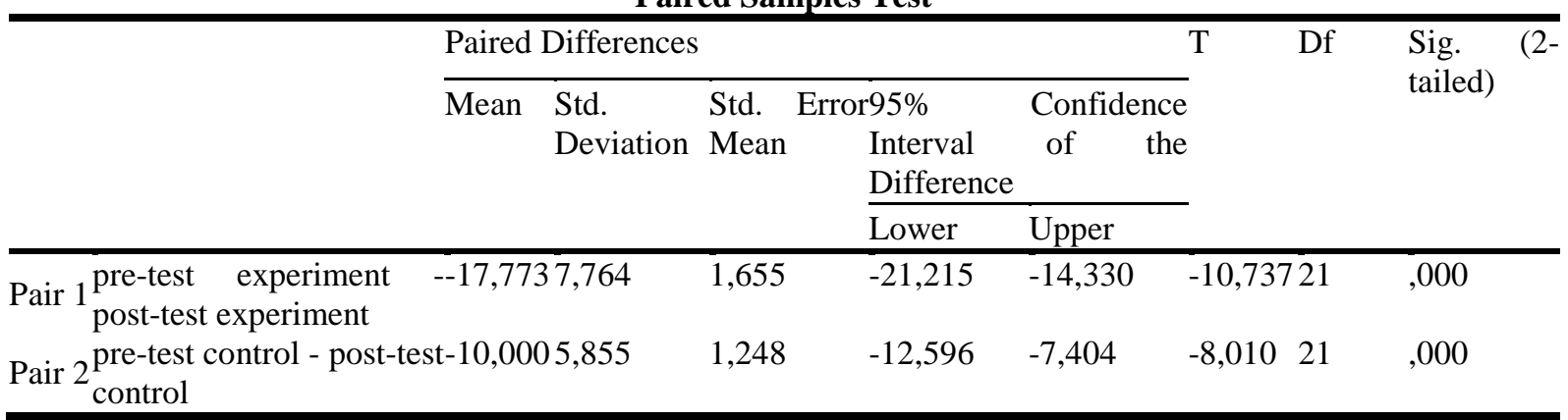


Based on the output results above can be interpreted that pair 1 obtained a significant value of $0.000<0.05$, it can be concluded that there is a difference in the average student learning outcomes for the pre-test experimental class and the control class post-test. The par 2 obtained a significant value of $0.000<0.005$, it can also be concluded that there is a difference in the average student learning outcomes for the control class pre-test class and the control class post-test. Based on these results, it can be concluded that blended learning is an effect on students' conceptual understanding. To find out how much influence blended learning has on students' conceptual understanding, it can be seen in the descriptive data below.

\section{Homogeneity Test}

Homogeneity Test of Variance

\begin{tabular}{llcccc}
\hline & & Levene Statistic & df1 & df2 & Sig. \\
\hline \multirow{5}{*}{ Understanding concept } & Based on Mean &, 674 & 1 & 42 &, 416 \\
& $\begin{array}{l}\text { Based on Median } \\
\text { Based on Median and with } \\
\text { adjusted df }\end{array}$ &, 672 & 1 & 42 &, 417 \\
& Based on trimmed mean &, 672 & 1 & 33,081 &, 418 \\
\hline
\end{tabular}

Based on the output results above, it shows a significance value (sig) based on the mean of $0.416>0.05$; it can be concluded that the variance of the post-test data for the experimental class and the post-test control class is the same or homogeneous; therefore the sampler test requirements of the T-Test have been fulfilled.

\section{Independent Test}

\section{Independent Samples Test}

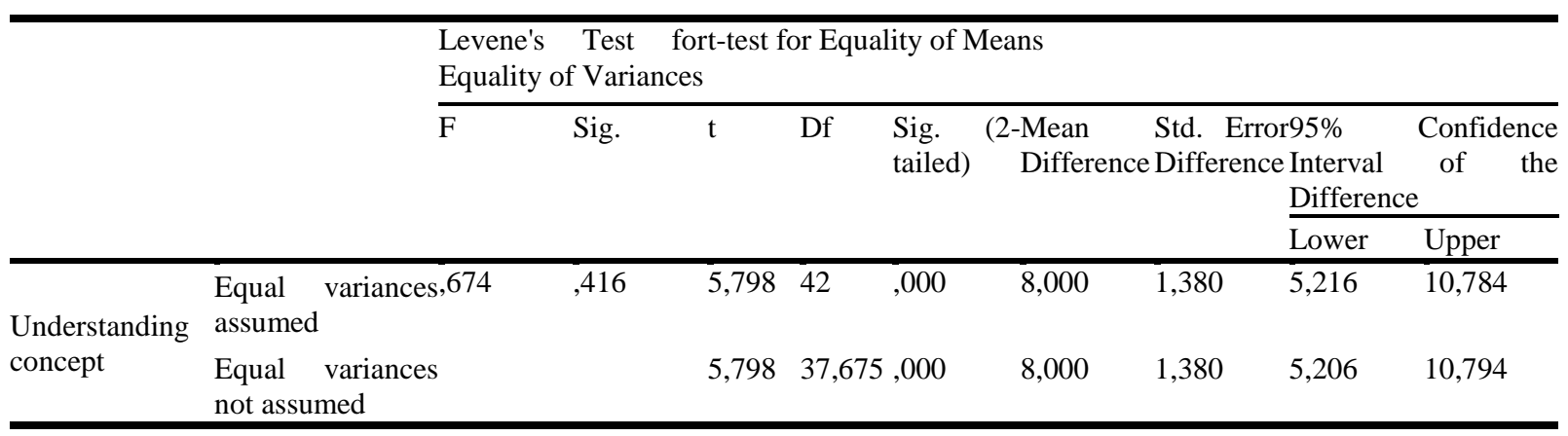

The independent test shown in the output above shows the sig (2-tailed) value of $0.000<0.05$, so there is a difference in the average student learning outcomes between using blended learning and using conventional learning, as for finding out how big the difference is between the learning outcomes of blended learning and conventional learning, namely as the following descriptive data.

\section{Group Statistics}

\begin{tabular}{|c|c|c|c|c|c|c|}
\hline & Class & $\mathrm{N}$ & Mean & $\begin{array}{c}\text { Std. } \\
\text { Deviation }\end{array}$ & $\begin{array}{l}\text { Std. } \\
\text { Mean }\end{array}$ & Error \\
\hline \multirow{2}{*}{ Understanding concept } & Post-test Experiment & 22 & 85,68 & 3,721 & ,793 & \\
\hline & Post-test Control & 22 & 77,68 & 5,295 & 1,129 & \\
\hline
\end{tabular}

These data show the average result of learning outcomes in the experimental class is 85.68 while the control class is 77.68. So it can be concluded that blended learning is more effective and efficient than conventional learning. 


\section{Discussion}

In the research results mentioned above, there are differences in blended learning results with conventional learning. While learning is more effective than conventional learning, as is also done at Moscow State University, the implementation of blended learning shows students' ability and professionalism (Nazarenko, 2015). Through the learning design that has been developed by the researcher combining sharing media and learning resources through links or learning resources designed by the researcher then applying it to the learning device, namely in Google Classroom, as well as distributing questions or quizzes that make it easier for lecturers and students to evaluate learning media subjects

Blended learning has the advantage that students can prepare learning because online learning material is provided in the learning application that has been provided. Therefore, it can make it easier for students to carry out learning and easily accept lecturers' learning materials. Besides, students can discuss with friends either online or face-to-face in the learning room (Kashefi et al., 2012).

Through the design of learning media by providing various learning resources in it, it provides facilities as a tool to find out the material that will be and is being delivered by the Lecturer. The use of instructional media with attractive designs is expected to be more enthusiastic and attractive to access learning materials. The Lecturer prepares instructional videos with tutorials to make learning media and publishes them in learning applications(Chafiq et al., 2014).It is hoped that it will make it easier for students to access even remote situations and increase student potential and easily understand learning material.

The presentation of blended learning is designed to activate students in the learning process, that they are not learning objects but learning subjects for productivity, which in the end, students understand in detail and in-depth regarding the making of learning media. Lecturers only act as facilitators, mediators provide learning resources, provide features for communication with fellow students as well as with lecturers

\section{Conclusion}

Through the development of information and communication technology used in the world of education, one of them is blended learning, which combines online and face-to-face learning. The research-based on the results that students who learn using blended learning has higher results than conventional learning. It makes students receive lessons faster and make learning more attractive, effective, and efficient in reconciling material

\section{References}

Atia, S., \&Elsaid, M. (2000). Blended Learning Based on Creative Approach : Enhancing The Mutual Impact of Creativity , Intrinsic Motivation and Achievement in Academic Camputer Courses. 1735(16), 53-65.

Berga, K. A., Vadnais, E., Nelson, J., Johnston, S., Buro, K., Hu, R., \&Olaiya, B. (2021). Blended learning versus face-to-face learning in an undergraduate nursing health assessment course: A quasi-experimental study. Nurse Education Today, 96(May 2020), 104622. https://doi.org/10.1016/j.nedt.2020.104622

Buran, A., \&Evseeva, A. (2015).Prospects of Blended Learning Implementation at Technical University.Procedia - Social and Behavioral Sciences, 206(November), 177-182. https://doi.org/10.1016/j.sbspro.2015.10.049

Chafiq, N., Benabid, A., Bergadi, M., Touri, B., Talbi, M., \& Lima, L. (2014).Advantages and Limits of the Implementation of Blended Learning for Development of Language Skills in Scientific Students.Procedia Social and Behavioral Sciences, 116, 1546-1550. https://doi.org/10.1016/j.sbspro.2014.01.432

Cohen, D. (1998). Chronicle of Higher Education.The Women's Review of Books, 15(5), 27. https://doi.org/10.2307/4022859

Kashefi, H., Ismail, Z., Yusof, Y. M., \&Rahman, R. A. (2012). Supporting Students Mathematical Thinking in the Learning of Two-Variable Functions Through Blended Learning. Procedia - Social and Behavioral Sciences, 46(2004), 3689-3695. https://doi.org/10.1016/j.sbspro.2012.06.128

Köse, U. (2010). A blended learning model supported with Web 2.0 technologies. Procedia - Social and Behavioral Sciences, 2(2), 2794-2802. https://doi.org/10.1016/j.sbspro.2010.03.417

Krasnova, T., \&Demeshko, M. (2015). Tutor-mediated Support in Blended Learning. Procedia - Social and Behavioral Sciences, 166, 404-408. https://doi.org/10.1016/j.sbspro.2014.12.544

Miyazoe, T., \& Anderson, T. (2010).Learning outcomes and students' perceptions of online writing: Simultaneous implementation of a forum, blog, and wiki in an EFL blended learning setting. System, 38(2), 185-199. https://doi.org/10.1016/j.system.2010.03.006

Nazarenko, A. L. (2015). Blended Learning vs Traditional Learning: What Works? (A Case Study Research).Procedia - Social and Behavioral Sciences, 200(October), 77-82. https://doi.org/10.1016/j.sbspro.2015.08.018 
Prasad, P. W. C., Maag, A., Redestowicz, M., \& Hoe, L. S. (2018). Unfamiliar technology: Reaction of international students to blended learning. Computers and Education, 122, 92-103. https://doi.org/10.1016/j.compedu.2018.03.016

Schober, A., Schober, A., \& Keller, L. (2012).International journal of emerging technologies in learning.International Journal of Emerging Technologies in Learning (IJET), 7(2012), 37-41. https://www.learntechlib.org/p/44977/

Sriarunrasmee, J., Techataweewan, W., \&Mebusaya, R. P. (2015).Blended Learning Supporting Self-Directed Learning and Communication Skills of Srinakharinwirot University's First Year Students.Procedia - Social and Behavioral Sciences, 197(February), 1564-1569. https://doi.org/10.1016/j.sbspro.2015.07.111

Sukendro, S., Habibi, A., Khaeruddin, K., Indrayana, B., Syahruddin, S., Makadada, F. A., \& Hakim, H. (2020).Using an extended Technology Acceptance Model to understand students' use of e-learning during Covid-19: Indonesian sport science education context.Heliyon, 6(11), e05410. https://doi.org/10.1016/j.heliyon.2020.e05410 